\title{
Nutritional potential of dehydrated residues from rice milk production
}

\author{
Silva, L. R..$^{a^{*}}$; Casari, A. C. A. B. ${ }^{\text {a }}$ Velasco, J. I. ${ }^{\text {b }}$ Fakhouri, F. M. ${ }^{\text {ab }}$ \\ ${ }^{a}$ Faculty of Engineering, Federal University of Grande Dourados. Dourados, MS, Brazil.

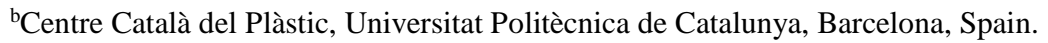

*E-mail of the corresponding author: luanramosea@gmail.com

\begin{abstract}
The aim of this work was to verify the influence of drying on physical and chemical characteristics of residues from rice milk production. Residues were from the production of white, red and black rice. They were dehydrated in an oven with air circulation at $60^{\circ} \mathrm{C}$ for $8 \mathrm{~h}$. Characterization of them were carried out by physical and chemical analyses. Residues have presented statistical difference for all parameters measured. Its characterization is necessary to justify its use in other process or application on new products.The residues from rice milk production have high content of nutrients and phenolic compounds, even after dehydration.
\end{abstract}

Keywords: Nutrients; Oryza sativa; waste. 


\section{Introduction}

Rice is one of the most consumed cereal in the world, mainly in Asian countries ${ }^{[1]}$. Its sucess is related not only on its nutritional quality or its practicality and applicability on food industry, but also on some characteristics that this grain present, like absence of allergenic substances and gluten ${ }^{[2]}$. In addition, rice has presented in its composition a high amount of proteins, mineral salts and B vitamins, and a low percentage of lipids, which confer a great nutritional value to the grain and make it a source of energy ${ }^{[3,4]}$.

There are many variety of rices, and some of them, like red or black rice, are source of compounds important for human nutrition. Red and black rice can be considered a source of important compounds for human nutrition and health, such as phenolic compounds, anthocyanins, catechins, and fibers ${ }^{[5,6,7]}$.

Vegetable milk is considered an option for dairy products. It is defined as an aquous extact made by vegetable raw materials ${ }^{[8]}$. Comparing with cow milk it stand out based on its composition, that presents low fat, cholesterol free, and high percentage of proteins and energy ${ }^{[9]}$. In addition it is lactose free ${ }^{[10]}$ and made by vegetables, so lactose intolerants and vegans can drink it.

Although vegetable milk is an important food product for consumers, its process generate some residues. Those residues produced still has important compounds which can be used in human diet. An alternative is the dehydration of this material and its application in many other food products. Thus, food industries could reduce its waste of resources on the environment.

The dehydration of residues from food industries is a way to preserve this material by loss of water, however processing and storage conditions have to be studied with the aim of preserving nutrients and bioactive compounds. So, it can be inserted in formulations of many kinds of foods, such as cereal bars, cakes, biscuits, among others.

Thereby, the aim of this work was to verify the influence of drying on physical and chemical characteristics of residues from the production of rice milk.

\section{Materials and Methods}

Residues were from the production of vegetable milk based on white, red and black rice. They were dehydrated in an oven with air circulation at $60^{\circ} \mathrm{C}$ for 8 hours. The characterization of them were carried out by analyses of moisture, ash, lipids, proteins, carbohydrates, total caloric value, $\mathrm{Aw}, \mathrm{pH}$, titratable acidity and phenolic compounds. 
Moisture content was quantified according to AOAC ${ }^{[11]}$. Samples were submitted to an oven with air circulation $\left(70^{\circ} \mathrm{C}\right.$ for 24 hours) and results expressed in percentage of moisture in wet basis. Ash was carried out by incineration in muffle oven at $550^{\circ} \mathrm{C}^{[11]}$, and results expressed in percentage of ash. Lipid was carried out by cold extraction ${ }^{[12]}$ and expressed as percentage of lipids. The determination of protein was done by micro Kjeldahl method and results calculated by conversion factor for rice (5.95) and expressed as percentage of proteins. Carbohydrate was calculated by difference (Nifext fraction). Total caloric value was calculated by multiplicated values of lipid, protein and carbohydrate by Atwater constants and expressed in kcal/100 grams. Water activity (Aw) was carried out by direct measurement in digital hygrometer (Aqualab, Decagon, 3.0 Serie). pH was measured directly with potenciometer, by diluation of $10 \mathrm{~g}$ of sample in $100 \mathrm{~mL}$ of distillated water. Titratable acidity was determined by titulation with sodium hydroxid ${ }^{[11]}$ and expressed in percentage.

For determination of phenolic compounds, extracts were made according to Rufino et al. ${ }^{[13]}$. The phenolic compounds were determined by Folin and Ciocalteau method ${ }^{[14]}$, developed by Singleton and Rossi ${ }^{[15]}$, with gallic acid as standart. Results were expressed as $\mathrm{mgEAG} / \mathrm{g}$.

All analyses were carried out in triplicate and datas were submitted to variance analyse and compared by Tukey test, with $5 \%$ of significance.

\section{Results and Discussion}

Residues from vegetable milk based on white, red and black rice (Fig. 1) have presented statistical difference $(\mathrm{p} \leq 0.05)$ for all parameters measured (Table 1 and 2 ).

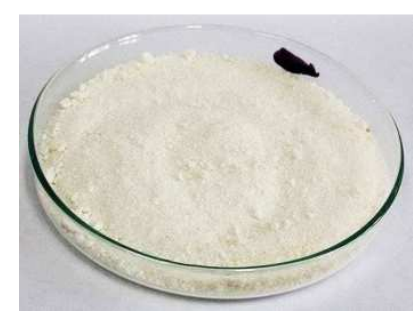

(a)

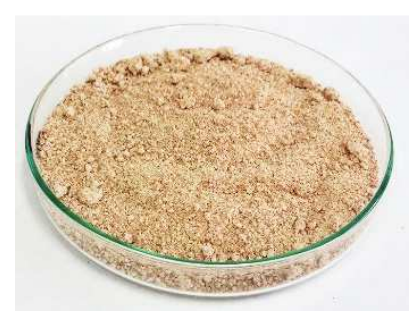

(b)

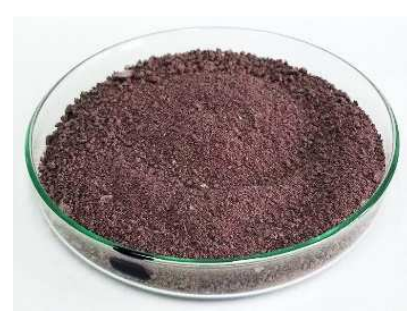

(c)

Fig. 1 Dehydrated residues from processing of vegetable milk based on white (a), red (b) and black (c) rice. 
Table 1. Characterization of residues from processing of vegetable milk based on white, red and black rice (part I).

\begin{tabular}{lccccc}
\hline Rice & Moisture (\%) & Ash (\%) & Lipid (\%) & Protein (\%) & Carbohydrate (\%) \\
\hline White & $4.11 \pm 0.10^{\mathrm{b}}$ & $0.45 \pm 0.01^{\mathrm{c}}$ & $0.45 \pm 0.07^{\mathrm{b}}$ & $7.56 \pm 0.32^{\mathrm{c}}$ & $87.43 \pm 0.49^{\mathrm{a}}$ \\
Red & $7.85 \pm 0.56^{\mathrm{a}}$ & $0.99 \pm 0.04^{\mathrm{b}}$ & $2.05 \pm 0.13^{\mathrm{a}}$ & $12.39 \pm 0.08^{\mathrm{a}}$ & $76.73 \pm 0.64^{\mathrm{c}}$ \\
Black & $2.13 \pm 0.04^{\mathrm{c}}$ & $1.19 \pm 0.07^{\mathrm{a}}$ & $1.81 \pm 0.16^{\mathrm{a}}$ & $10.75 \pm 0.02^{\mathrm{b}}$ & $84.12 \pm 0.06^{\mathrm{b}}$ \\
\hline
\end{tabular}

According to the composition of residues, protein value is an important parameter that can be observed. Residue from red rice milk presented $12.39 \%$ of protein, and make it as a great source of this macronutrient.

Table 2. Characterization of residues from processing of vegetable milk based on white, red and black rice (part II).

\begin{tabular}{lccccc}
\hline Rice & $\begin{array}{c}\text { Total caloric } \\
\text { value* }\end{array}$ & Aw & $\mathrm{pH}$ & $\begin{array}{c}\text { Titratable } \\
\text { acidity (\%) }\end{array}$ & $\begin{array}{c}\text { Phenolic } \\
\text { compounds** }\end{array}$ \\
\hline White & $384.05 \pm 0.10^{\mathrm{b}}$ & $0.248 \pm 0.005^{\mathrm{b}}$ & $5.93 \pm 0.07^{\mathrm{b}}$ & $1.65 \pm 0.07^{\mathrm{c}}$ & $19.30 \pm 0.60^{\mathrm{c}}$ \\
Red & $374.01 \pm 0.70^{\mathrm{c}}$ & $0.527 \pm 0.002^{\mathrm{a}}$ & $6.11 \pm 0.07^{\mathrm{a}}$ & $374.01 \pm 0.70^{\mathrm{c}}$ & $110.26 \pm 0.01^{\mathrm{b}}$ \\
Black & $395.13 \pm 0.63^{\mathrm{a}}$ & $0.195 \pm 0.000^{\mathrm{c}}$ & $6.20 \pm 0.02^{\mathrm{a}}$ & $3.98 \pm 0.09^{\mathrm{a}}$ & $123.41 \pm 0.50^{\mathrm{a}}$
\end{tabular}

*kcal/100 grams; **mg EAG/100 g. Values in the same column followed by the same letter do not differ by Tukey test at $5 \%$ of probability.

The characterization of residues from food industry is necessary to justify its use in other process or application on the development of new food products, such as cereal bars, cookies, breads, biscuits, cakes, and others. Using up all nutrients and reducing the waste of them and the environmental impact.

Dehydration process do not degraded the content of phenolic compounds present on the samples. Residue from black rice milk presented highest phenolic compounds content 
(123.41 mg EAG/100 g), due to the difference on the variety of rices (white: $19.30 \mathrm{mg}$ EAG/100 g; red: $110.26 \mathrm{mg}$ EAG/100 g).

Even after dehydration, residues still presented a great content of nutrients and bioactive compounds. Many researchers use the dehydration of residues to make flours and use it in new food products. So all important nutrients and compounds is used and consumed by people.

\section{Conclusions}

In conclusion, residues from rice milk production have high content of nutrients and phenolic compounds, even after dehydrated. Also they can be used on others process to improve the nutritional quality of new food products and reduce the waste of nutrients. Dehydration, at the studied conditions, of the residues from rice milk production is an indicated process for preservation of nutrients and bioactive compounds.

\section{Acknowledgment}

Authors are grateful to Coordination for the Improvement of Higher Education Personnel (CAPES) for scholarship and TECNIOspring program.

\section{References}

[1] Folorunso, A. A.; Omoniyi, S. A.; Habeeb, A. S. Proximate composition and sensory acceptability of snacks produced from broken rice (Oryza sativa) flour. American Journal of Food \& Nutrition 2016, 6 (2), 39-43.

[2] Silva, R. F.; Ascheri, J. L. R. Extrusão de quirera de arroz para uso como ingrediente alimentar. Brazilian Journal of Food Technology 2009, 12, 190-199.

[3] Carvalho, A. V.; Bassinello, P. Z.; Mattietto, R. A.; Carvalho, R. N.; Rios, A. O.; Seccadio, L. L. Processamento e caracterização de snack extrusado a partir de farinhas de quirera de arroz e de bandinha de feijão. Brazilian Journal of Food Technology 2012, 15 (1), 72-83.

[4] Walter, M.; Marchezan, E.; Avila, L. A. Arroz: composição e características nutricionais. Ciência Rural 2008, 38 (4), 1184-1192.

[5] Hayashi, S.; Yanase, E. A study on the color deepening in red rice during storage. Food Chemistry 2016, 199, 457-462. 
[6] 21. Hu, Z.; Tang, X.; Liu, J.; Zhu, Z.; Shao, Y. Effect of parboiling on phytochemical content, antioxidant activity and physicochemical properties of germinated red rice. Food Chemistry 2017, 214, 285-292.

[7] Mau, J. L.; Lee, C. C.; Chen, Y. P.; Lin, S. D. Physicochemical, antioxidant and sensory characteristics of chiffon cake prepared with black rice as replacement for wheat flour. LWT - Food Science \& Technology 2017, 75, 434-439

[8] Izadi, T.; Izadi, Z.; Tehrani, M. M.; Pour, M. A.; Moghadam, M. Z.; Shariaty, M. A. Investigation of Optimized Methods for Improvement of Organoleptical and Physical Properties of Soymilk. International Journal of Farming and Allied Sciences 2013, 2 (10), 245-250.

[9] Rehman, S.; Nawaz, H.; Ahmad, M. M.; Hussain, S.; Murtaza, A.; Shahid, S. H. Physico-chemical and sensory evaluation of ready to drink soy-cow milk based. Pakistan Journal of Nutrition 2007, 6 (3), 283-285.

[10] Ikya, J. K.; Gernah, D. I.; Ojobo, H. E.; Oni, O. K. Effect of Cooking Temperature on Some Quality Characteristics of Soy Milk. Advanced Journal of Food Science \& Technology 2013, 5 (5), 543-546.

[11] ASSOCIATION OF OFFICIAL AGRICULTURE CHEMISTS. Official methods of analysis of the Association of Official Agriculture Chemists. 18 ed. Mayland: AOAC, 2005.

[12] Bligh, E. G.; Dyer, W. J. A rapid method of total lipid extraction and purification. Canadian Journal of Biochemistry and Physiology 1959, 37 (9), 911-917.

[13] Rufino, M. S. M.; Alves, R. E.; Brito, E. S.; Morais, S. M.; Sampaio, C. G.; PérezJiménez, J.; Saura-Calixto, F. D. Metodologia Científica: Determinação da atividade antioxidante total em frutas pela captura do radical livre DPPH. Comunicado técnico EMBRAPA 2007, 127, 1-4.

[14] Folin, O.; Ciocalteau, V. On tyrosine and tryptophane determinations in pronteins. The Journal of Biological Chemistry 1927, 73, 627-650.

[15] Singleton, V. L.; Rossi Junior, J. A. Colorimetric of total phenolics with phosphomolybdic phosphotungstic acid reagents. American Journal of Enology and Viticulture 1965, 16, 144-158. 